\title{
Commercialization of Fuel-Cells
}

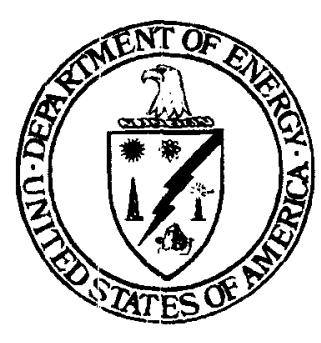

March 1995

U.S. Department of Energy Office of Energy Research Office of Program Analysis 
This report has been reproduced directly from the best available copy.

Available to DOE and DOE Contractors from the Office of Scientific and Technical Information, P.O. Box 62, Oak Ridge, TN 37831; prices available from (615) 576-8401.

Available to the public from the U.S. Department of Commerce, Technology Administration, National Technical Information Service, Springfield, VA 22161, (703) $487-4650$. 


\section{DISCLAIMER}

This repor was prepared as an account of work sponsored by an agency of the United States Government. Neither the United States Government nor any agency thereof, nor any of their employees, makes any warranty, express or implied, or assumes any legal liability or responsibility for the accuracy, completeness, or usefulness of any information, apparatus, product, or process disclosed, or represents that its use would not infringe privately owned rights. Reference herein to any specific commercial product, process, or service by trade name, trademark, manufacturer, or otherwise does not necessarily constitute or imply its endorsement, recommendation, or favoring by the United States Government or any agency thereof. The views and opinions of authors expressed herein do not necessarily state or reflect those of the United States Government or any agency thereof. 


\section{DISCLAIMER}

Portions of this document may be illegible in electronic image products. Images are produced from the best available original document. 


\section{Commercialization of Fuel-Cells \\ by}

S.S. Penner (UCSD), ‡ A.J. Appleby (Texas A\&M), B.S. Baker (ERC), J. L. Bates (PNL), L.B. Buss (AlliedSignal), W.J. Dollard (Westinghouse), P.J Farris (IFC), E.A. Gillis (EPRI), J.A. Gunsher (Dow), A. Khandkar (Ceramatec), M. Krumpelt (ANL), J.B. O'Sullivan (EPRI), G. Runte (GPU), R.F. Savinell (CWR), J.R. Selman (IIT), D.A. Shores (UM), and P. Tarman (M-C Power)

¥Center for Energy and Combustion Research and Department of Applied Mechanics and Engineering Sciences, University of California/San Diego, 9500 Gilman Drive, La Jolla, CA 92093-0411

Abstract - We describe fuel-cell commercialization for stationary power applications of phosphoric acid, molten carbonate, solid oxide, and polymer electrolyte membrane fuel cells.

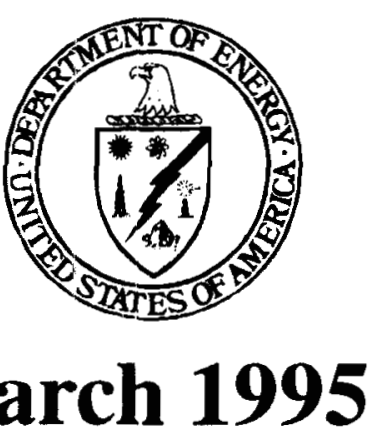

\section{U.S. Department of Energy Office of Energy Research Office of Program Analysis Germantown, MD 20874}

This is an abbreviated version of the "Report of the DOE Advanced Fuel Cell Commercialization Working Group (AFC2WG)", released January 30, 1995. The work was performed under U.S. DOE Grant No. DEFG0393ER0213, DOE Office of Energy Research, to the Regents of the University of California. F.D. Freeburn served as DOE Technical Project Officer. In addition to the listed authors, the following were AFC2WG study participants: L. Camara (M-C Power), T.-P. Chen (Bechtel), H.F. Creveling (Allison), S.H. Folstad (IFC), R.B. Fleming (Ballard), M. Hsu (Ztek), J.J. Kennedy (AlliedSignal), J.A. Kimball (GRI), K. Krist (GRI), J.W. Landis (Stone \& Webster), L.G. Marianowski (IGT), H. Maru (ERC), L.T. Papay (Bechtel), M. Raber (GPU), R. Rosenthal (DOE), S. Swathirajan (GM), and J. Talbot (UCSD); Ex officio participants included S.G. Chalk (DOE), E.J. Caims (LBL), L.H. Dubois (ARPA), R.A. Lemons.(LANL), M.J. Mayfield (DOE, deceased 09-0894), P.G. Patil (DOE), and C.E. Pax (DOE). All of the participants provided inputs, criticism and advice which is gratefully acknowledged.

$\ddagger$ Chairman of the Working Group; author for correspondence. 



\section{COMMERCIALIZATION OF FUEL CELLS ${ }^{\dagger}$}

by

S.S. Penner (UCSD) $\ddagger$ A.J. Appleby (Texas A\&M), B.S. Baker (ERC), J. L. Bates (PNL), L.B. Buss (AlliedSignal), W.J. Dollard (Westinghouse), P.J. Farris (IFC), E.A. Gillis (EPRI), J.A. Gunsher (Dow), A. Khandkar (Ceramatec), M. Krumpelt (ANL), J.B. O'Sullivan (EPRI), G. Runte (GPU), R.F. Savinell (CWR), J.R. Selman (IIT), D.A. Shores (UM), and P. Tarman (M-C Power)

¥Center for Energy and Combustion Research and Department of Applied Mechanics and Engineering Sciences, University of California/San Diego, 9500 Gilman Drive, La Jolla, CA 92093-0411

Abstract - We describe fuel-cell commercialization for stationary power applications of phosphoric acid, molten carbonate, solid oxide, and polymer electrolyte membrane fuel cells.

$\dagger$ This is an abbreviated version of the "Report of the DOE Advanced Fuel Cell Commercialization Working Group (AFC2WG)", released January 30, 1995. The work was performed under U.S. DOE Grant No. DEFG0393ER0213, DOE Office of Energy Research, to the Regents of the University of California. F.D. Freeburn served as DOE Technical Project Officer. In addition to the listed authors, the following were AFC2WG study participants: L. Camara (M-C Power), T.-P. Chen (Bechtel), H.F. Creveling (Allison), S.H. Folstad (IFC), R.B. Fleming (Ballard), M. Hsu (Ztek), J.J. Kennedy (AlliedSignal), J.A. Kimball (GRI), K. Krist (GRI), J.W. Landis (Stone \& Webster), L.G. Marianowski (IGT), H. Maru (ERC), L.T. Papay (Bechtel), M. Raber (GPU), R. Rosenthal (DOE), S. Swathirajan (GM), and J. Talbot (UCSD); Ex officio participants included S.G. Chalk (DOE), E.J. Cairns (LBL), L.H. Dubois (ARPA), R.A. Lemons (LANL), M.J. Mayfield (DOE, deceased 09-0894), P.G. Patil (DOE), and C.E. Pax (DOE). All of the participants provided inputs, criticism and advice which is gratefully acknowledged.

$¥$ Chairman of the Working Group; author for correspondence. 


\section{Overview}

The AFC2WG Report deals with an assessment of requirements to advance fuel-cell (FC) system manufacture, marketing and sales to the point where publicly or privately held organizations can operate profitably in the international, competitive, stationary power-equipment market of the twenty-first century. Statements in italics constitute an abbreviated overview of this Summary and may be read independently of the remaining text. FCs convert chemical energy not first to heat but directly to electricity. Their efficiencies are not determined by the Carnot-cycle limits which provide upper bounds for all present-day steam-cycle power plants. The current development levels and readiness for commercialization of different $F C$ systems are greatly different. ${ }^{\dagger}$ An assembly of FCs constitutes an FC stack. An FC system consists of the FC stack and the balance of plant (BOP). The mature FC-stack cost typically represents about one third of the FC-system cost. Reflecting a wide range of potential applications and commercial interests, the status of four different FC stacks has been assessed [the words preceding "fuel cells" identify the electrolyte that is used: phosphoric acid fuel cells (PAFCs), molten carbonate fuel cells (MCFCs), tubular and planar solid oxide fuel cells (SOFCs), and proton-exchange membrane fuel cells (PEMFCs $\ddagger$ )].

\section{Activities and Studies Leading to this Report}

Some or all of the members of the Working Group participated in detailed studies, policy discussions and other activities as follows: seven technical meetings and discussions, site visits to facilities of U.S., Japanese and European FC-stack manufacturers and to operating FC systems in the U.S. and Japan, and assessments of the supporting RD\&D programs in the U.S., Japan and Europe performed in industrial, national and university laboratories. The Working Group also received inputs from utility executives, construction engineers, and managers of federal and industry-cooperative programs. In addition, advice was solicited from executives of large industrial firms and from successful private entrepreneurs on critical issues encountered in the past commercialization of selected advanced technologies other than FCs.

† Typical operating temperatures (in degrees C) increase from about 100 for PEMFCs to 200 for PAFCs to 650 for MCFCs to 950 1050 for SOFCs.

\$ Since PEMFCs are expected to find preferred applications in the transportation sector, the synergism for applications in the stationary and transportation areas has been examined to some extent. 


\section{Commercialization of FC Systems is in the National Interest}

FC systems may become the first important replacements, using fossil fuels for diverse stationary and mobile power applications, in more than a century for high-temperature combustion systems because of the following advantages: (a) FC systems are environmentally clean with emissions of regulated pollutants (e.g., $N O_{x}$ ) far below currently applicable and anticipated future control levels. Since FC systems for stationary power applications are expected to enter preferentially the on-site, distributed power market, there will be cost savings in transmission and distribution and also relief concerning the perception of health problems caused by long-distance, high-power electricity-transmission lines. FC systems will initially use natural gas (NG); they may, however, be operated with many different fuels, including hydrogen. The commercialization of FC systems is therefore compatible with the long-range goal of ultimately replacing a fossil-fuel-based by a hydrogen-based economy. (b) FC systems will have higher fossil-fuel energy-conversion efficiencies to electricity and useful heat or to motion than the best of the competing combustion technologies, thereby contributing importantly to the potential for reducing the cost of electricity, to energy conservation and reductions in $\mathrm{CO}_{2}$ emissions per unit of useful output energy, which will facilitate meeting U.S. treaty obligations on $\mathrm{CO}_{2}$-emission reductions over the long term. PAFC systems are the first FC power-conversion units that have reached significant market-demonstration status at fuel-to-electricity conversion efficiencies in the range of 40 to $42 \%$, which is well above the national average of about $37 \%$ for mature baseload fossil-fuel systems; overall PAFC-system efficiencies above $80 \%$ have been achieved in cogeneration applications. The use of appropriate FC systems in transportation applications is expected to yield about double the fuel-energyto-distance conversion efficiency that is achieved with the best vehicles using internal combustion engines. (c) FC stacks and the complete FC systems are high-technology power-conversion units for the twenty-first century. FC construction, installation and operation will create numerous high-technology and supporting jobs. (d) FC commercialization reflects an international agenda in RD\&D and sales. Very large markets for FCs are foreseen in distributed power generation and many industrial sectors for both developed and lessdeveloped countries. Maintenance of a desirable U.S. competitive position requires dedicated pursuit of FC development beyond the stage of initial market demonstration to full, cost-competitive commercial entry in a highly competitive international environment. Rapid commercialization of FC systems is in the national interest 
and foreign governmental support of foreign $F C$ developers requires continued U.S. governmental support of U.S. manufacturers in order to maintain a level playing field in international competition.

\section{Successful Market Demonstration has been Achieved for the First of the Fuel-Cell Systems}

The introduction of any new technology is fraught with difficulties. Replacement of mature power equipment and of internal combustion engines by FC systems, after more than 100 years of technology improvements of conventional systems which continue to this day with expenditure levels far above those allocated for FC commercialization, poses special problems to developers and entrepreneurs. The first crucial hurdle that sellers of the new technology must overcome is market acceptability for the new types of systems. The crucially important first test of market acceptability for FC systems has been passed successfully with demonstration sales of the PC25 $5^{T M}$ PAFC systems manufactured by the ONSI unit of the International Fuel Cell Corporation (IFC, a subsidiary of United Technologies Corporation) and assembled into operating systems with complete BOP. IFC has delivered 342 power plants in 18 models with a total installed capacity of $37,000 \mathrm{~kW}$ and accumulated operating experience of 900,000 hours. Included in this set are about forty 200-kW operating units worldwide designated as $P C 25^{\mathrm{TM}}$ power plants. On the basis of independent personal discussions with users and operators of a number of PC25 ${ }^{\mathrm{TM}}$ plants, we can attest to each of the following performance achievements: high reliability, advertised performance, excellent maintenance, assured customer satisfaction and compatibility with system requirements and outputs in the electric- and gas-utility sectors and for independent power applications. These results should mean that future market acceptance of all FC systems will not suffer from lack of familiary with FC technology. 


\section{Public Investments Are Needed and Justified for Expeditious FC Commercialization}

\section{(a) Successful Private-Sector Commercialization of New Technologies}

The successful commercialization of any new technology must meet a number of stringent business constraints. ${ }^{\dagger}$ In the private sector, fund allocations for FC commercialization must compete with other business opportunities. Because of emphasis on the near-term bottom line, any new technology with a time horizon for return on investment longer than about 3 years is at a significant disadvantage with respect to alternatives offering shorter periods for returns on investment. In this regard, the U.S. economic system may place the country at a disadvantage in international competition. $\neq$

\section{Public-Sector Investments for the Commercialization of U.S. FC Technologies are Appropriate}

It is possible to build a consensus that a new technology offers public goods to such an extent that its entry into the marketplace should be partially supported at public expense, as long as it is relatively untried and expensive when first marketed. As stated in Sec. I-2, FC-system commercialization merits public-sector investments because of environmental cleanliness, high efficiency, anticipated contributions to high-technology job creation, and augmentation of the U.S. balance of trade. Federal funds have been expended on FC development for at least 40 years. Cost reductions of FCs with increasing production have been normal. Although technical challenges remain for some of the $\mathrm{FC}$ systems, the primary current issue is implementation of a large-scale commercialization agenda, coupled with $R \& D$ directed at product improvement. Without investment subsidies, there may be critical delays in large-scale construction and use of U.S. FC systems, which could prove to be serious impediments in international competition since it appears that very large investment

$\dagger$ Without government intervention, any new entry into the commercial market must have the following features: (i) it must be costcompetitive with the technologies it replaces; (ii) it must have a record of proven reliability in meeting the service warranties with which it is sold; (iii) it must have a service duration with reasonable replacement and operations and maintenance costs for the expected performance life; (iv) it must offer real or perceived operational advantages over competing technologies for successful marketing. There is a reasonable expectation that new technologies meeting the criteria (i) to (iv) will be supported by private venture capital prior to large-scale market entry. There are, however, numerous examples of new commercial devices which bankrupt venture capitalists as the result of commercialization efforts. The percentage of successful new entries of promising new technologies is probably smaller than $10 \%$. The chief causes for failures are well catalogued and generally stated in the following order of prevalence: (i) undercapitalization; (ii) failure to meet reliability estimates in the real world when operations were turned over to relatively unskilled personnel, thereby causing excessive repair costs; (iii) failure to implement successful marketing, i.e. inability to demonstrate the superiority of the new technology to the extent necessary for purchases by buyers who were fundamentally satisfied with the product mix they were using; (iv) failure to allow for the fact that many obsolete or obsolescent devices can be refurbished at much lower costs than purchases of an apparently cost-competitive new technology.

\# This issue has been well recognized and its optimal resolution with respect to FC commercialization is an appropriate investigation by another group such as a properly constituted committec; of the National Academy of Engineering. 
subsidies are made available to FC developers based in other countries. Maintenance of a desirable U.S. competitive position requires continued public-sector involvement until commercial status is reached.

\section{The U.S. FC-System Development Effort is Not Supported at the Level Required for Accelerated Commercialization in Highly Competitive International Markets}

Only PAFC systems have been produced, sold and applied under commercial operating conditions in sufficient numbers to justify projected cost estimations based on normal technology-learning curves. Using available information, we estimate that $\$ 100$ to $\$ 150$ million dollars of additional investments accompanying an accelerated sales program and use of a recently completed robotic production facility will be needed to reduce the IFC-ONSI system costs to the range of $\$ 1500-2000 / \mathrm{kW}$, at which level a substantial domestic and international commercial market niche may be expected to materialize. This program will raise the entire investment in PAFC-system commercialization from private, governmental and other not-for-profit sources to about $\$ 1$ billion, which is very much less than the total expenditures for commercialization and subsequent improvements of turbines for stationary power applications.

Westinghouse has produced and operated over 4,500 experimental tubular SOFCs. Two 25-kW stacks have been operated for more than 5000 hours in Japan. Larger scale (two to three 100 to $200 \mathrm{~kW}$ and one to three 1 to 2 MW) proof-of-concept units have been proposed by Westinghouse for the 1996-98 time frame, to be followed by precommercial 50- to 100-MW units in 1998. Substantial additional investments and production will be needed before tubular SOFCs can penetrate competitive commercial markets.

The commercialization efforts of large U.S. companies such as United Technologies, Westinghouse and AlliedSignal Corporations (see below) are being complemented by entrepreneurial activities of dedicated specialty enterprises of which Energy Research Corporation (ERC, a publicly traded company on the Nasdaq market) and M-C Power (MCP, a privately held company) are outstanding examples. According to ERC, over $\$ 200$ million (with fund sources about evenly split between the private and public sectors) have been spent on MCFC development since 1976 and about $\$ 250$ million in additional funding (including about $\$ 150$ million of public sector and partner investments) will be needed by 1998 to produce a commercial product. ERC has begun construction of their proprietary direct MCFC system at the 2-MW level in the form of a natural-gasfueled demonstration plant located at Santa Clara (CA), which is scheduled to deliver power to the city's grid 
system in 1995. MCP is developing another MCFC system based on a design designated as IMHEX $\circledast$ which uses internal manifolding to distribute fuel and air to individual cells. MCP technology has been verified on several 20-kW short stacks; a 250-cell stack and a 250-kW power plant are to be tested in 1994 and 1995. respectively. Subsequently required investments leading to commercial sales (i.e. units sold on a fixed-price basis with performance specifications, warranties and service policies) of the MCP technology are anticipated by MCP management to be in the same range as for the ERC technology. The two MCFC systems of ERC and MCP have elicited very substantial interest from potential user groups. Over 90 electric, gas and combination investor-owned and municipal utility companies and rural electric cooperatives, together with independent power producers and various $A \& E$ and vendor organizations, are supporting activities via MCP's Alliance to Commercialize Carbonate Technology (ACCT) and ERC's Fuel Cell Commercialization Group (FCCG). FCCG is a utility-buyer group with more than 35 companies paying $\$ 10,000$ per year to follow ERC's developments, cooperate on working committees and obtain the right to buy early commercial units. A subgroup of five FCCG utilities, the National Rural Electric Cooperative Association and the Electric Power Research Institute are sponsoring the BOP design, construction and test through the Santa Clara Demonstration Project for a $2-\mathrm{MW}$ power plant at a cost of $\$ 27$ million; construction of the FC stacks is funded by DOE. San Diego Gas and Electric Company and UNOCAL are cooperating with MCP to design and test 250-kW units, with DOE again funding the FC stack.

Planar (including monolithic) solid oxide fuel-cell system designs are described in the Manufacturers' presentations (Chapter $V$ of the AFC2WG Report) by workers at AlliedSignal, Ceramatec and Ztek. These promising systems are at earlier stages of development with total needed investments for successful commercialization not yet estimated.

PEMFCs are the primary system entries for transportation applications. ${ }^{\dagger}$ Ballard is the industry leader but there are also numerous U.S. and other foreign entries. The development of PEMFC systems will be accelerated through a joint effort of Dow Chemical Company and Ballard directed at commercialization of PEMFC systems for stationary applications within five years. Stationary systems of 10 and $30 \mathrm{~kW}$ have been tested on natural gas and hydrogen, respectively. Dow is currently manufacturing additional 10-kW prototypes

\footnotetext{
$\dagger$ Funding for transportation issues has not been assessed by this Working Group.
} 
and plans to commercialize a 250-kW natural-gas-fueled system within 5 years. The total Dow/Ballard program expenditures, including external investments over the next five years, are projected by DOW to be $\$ 250-350$ million.

U.S. Department of Energy funding for stationary $F C$ power plants has been running at a level of about $\$ 50$ million per annum and perhaps $15 \%$ of this amount is available in addition from the participating industrycooperative agencies represented by the Electric Power and Gas Research Institutes. The U.S. Advanced Research Projects Agency (ARPA) has provided \$15million in each of the last two years. It is thus evident that designated public and cooperative funding for FC RD\&D falls very far short of anticipated requirements for commercialization within a time frame of 3 to 5 years. The PAFC system will need sales orders plus investments of perhaps $\$ 150$ million dollars; the two MCFC systems will require at least $\$ 500$ million in additional investments; the Westinghouse tubular SOFC system is not likely to reach competitive status with lesser funding than either of the MCFC systems. Thus, the total immediate needs for these four systems are close to $\$ 1$ billion. The total development costs for planar SOFC systems and PEMFC systems for stationary power applications could easily double the five-year requirement to $\$ 2$ billion. Only about $15 \%$ of required investments is currently committed in the form of dedicated DOE and cooperative industry funding for stationary power systems. The conclusion appears inevitable that substantial additional public and private investments and subsidies will be needed to proceed from research and development or market demonstration to commercialization. ${ }^{\dagger}$

\section{FC-System Diversity Is an Essential Component of Current Commercialization Efforts}

Because of financial constraints, there may be a strong predilection to downsize the FC-system commercialization agenda through preselection of a small number of technologies as primary candidates. It is the view of the Working Group Members that preselection of FC systems in advance of commercialization should not be done for some years because of the greatly different designs, anticipated performance differences, and likely different preferred application areas for each of the FC technologies.

$\dagger$ This Working Group has not attempted to identify a preferred distribution of funding sources for commercialization subsidies. 


\section{The Current Status of FC Commercialization Efforts}

A tabular overview of the mid-1994 status of FC developments is given in Table I-1. Examination of this table shows each of the following: (i) the greatly different status with respect to commercialization of the different types of FC systems, (ii) the urgency of large numbers of sales for the PAFC systems, (iii) the nearterm need for successful operations of large-scale MCFCs and tubular SOFCs with complete BOP, (iv) the proliferation of competing entries for planar SOFCs and PEMFCs, (v) both the international cooperative and competitive features of the developing FC technologies.

\section{The Market for Commercial FC Systems}

The market includes: (i) on-site systems on the customer or utility side of the meter with requirements from a few tens of $\mathrm{kW}$ to a few $\mathrm{MW}$, (ii) substation systems from a few to tens of $\mathrm{MW}$, (iii) central station systems with outputs from 50 to hundreds of MW. For each power range, there are competing technologies at capital costs per $\mathrm{kW}$ of output well below those that can currently be met with FC systems. Nevertheless, for selected applications and regions and provided proper allowance is made for environmental and transmission and distribution advantages of the clean FC systems, the use of FC systems may allow delivery of lower-cost electricity to consumers than conventional technologies in preferred locations. While it is generally agreed that system costs of $\$ 1500 / \mathrm{kW}$ would be attractive in assuring market penetration, there are applications and situations where the competitive price is much higher (i.e. $\$ 2500-3000 / \mathrm{kW}$ ). It is also important to note that economic benefits to users of $F C$ power plants may result from entirely new application concepts that become possible because of the unique features of $F C$ systems. No reliable methodology exists for estimating the likely market share of the FC technologies as a function of time. However, the potential market (from 1995 to 2005, $100 \mathrm{GW}$ of new and of replacement U.S. capacity) is so large that only a small percentage of the total is required to assure the success of the FC commercialization effort.

The commercial entry of $F C$ technologies into the market place will be negatively affected by deregulation of the utility industries. Major structural changes have occurred first for the gas and now for the electric utilities. These industries have in the past pioneered new technologies. The associated risks have been moderated by monopoly status and allowance of rate-based costs to be passed on to customers. The new regulatory changes favor enhanced competition and lowest-cost providers. This change, coupled with after-the- 
fact prudency reviews, has inevitably led to a policy of avoidance of real or perceived risks. Electric utilities have begun to place generation assets into unregulated subsidiaries. As a result, it has become less likely that either utilities or their competitors will purchase high-cost market-entry units without subsidies from other entities. Properly valuing reliability and power quality, minimizing transmission and distribution (T\&D) investments, considering T\&D losses, and properly crediting emissions and efficiency benefits may, however, lead to acceptance of market-entry hardware with costs above the market clearing price. In the new market environment, the role of the government has become critical and new options may be needed for FC users and FC manufacturers.

FC-system purchases will be made because of the environmental and other advantages of using FC systems. A market may develop because the use of conventional combustion systems is interdicted as the result of one of the many real or perceived problems that accompany their use. However, all of these sales incentives combined will not lead to commercial success unless competitive costs for delivery of electricity at acceptable reliability and quality are achieved.

\section{The Need for a Continuing Product-Improvement Agenda}

All commercial systems require ongoing product-improvement programs for the purpose of reducing costs, improving performance, enhancing reliability, etc. Supporting $R \& D$ for FC-system product improvement is no exception. For these systems to take over a significant fraction of the future power-equipment market, R\&D will be required for a long time, as has been the case for coal burners, gas turbines, transportation systems, and all other high-technology devices. A detailed agenda of needed $R \& D$ leading to product improvement and cost reductions is given in the AFC2WG Report for each of the FC systems considered in the evaluation.

Serious budgetary constraints have been caused by the necessity of funding product-improvement R\&D tied to high-priority implementation of demonstration plants. The competition for $R \& D$ funds has resulted in underfunding of long-term basic research. This problem may be corrected with dedicated sources of support that cannot be diverted to urgent near-term uses on demonstration and commercialization activities. It is suggested by the Working Group that establishment of a multi-university Engineering Research Center dealing with complete FC systems, with appropriate multidisciplinary focus and guided by the FC manufacturing sector 
while receiving active support from staff personnel in National Laboratories, may be a useful adjunct to the FCcommercialization effort. 
Table I-1. Summary table on FC-commercialization status as of mid-1994; BOP means balance of plant.

\begin{tabular}{|c|c|c|c|c|c|c|c|c|c|c|}
\hline \multicolumn{2}{|c|}{ Fuel-Cell Type } & \multicolumn{2}{|c|}{$\begin{array}{l}\text { Demonstration } \\
\text { Sales } \\
\text { (Power Range) }\end{array}$} & \multicolumn{2}{|c|}{ Commercial Sales } & \multicolumn{2}{|c|}{$\begin{array}{c}\text { Stcps to } \\
\text { Commercialization }\end{array}$} & \multicolumn{2}{|c|}{$\begin{array}{l}\text { Technology } \\
\text { Leader(s) [Forcign } \\
\text { Associate(s)] }\end{array}$} & $\begin{array}{l}\text { Primary Foreign or US Competitors } \\
\text { [Other Important Entries] }\end{array}$ \\
\hline \multicolumn{2}{|c|}{ PAFC } & \multicolumn{2}{|c|}{$\begin{array}{c}1989-91 \\
(200 \mathrm{~kW} \text { to } 11 \\
\mathrm{MW})\end{array}$} & \multicolumn{2}{|c|}{ Since 1992} & \multicolumn{2}{|c|}{ Large SalesVolume } & \multicolumn{2}{|c|}{$\begin{array}{l}\text { IFC (US) [CLC } \\
\text { (Europe), Toshiba } \\
\text { (Japan)] }\end{array}$} & $\begin{array}{c}\text { Fuji (Japan) [ERC (US), Melco (Japan), } \\
\text { Sanyo (Japan)] }\end{array}$ \\
\hline \multicolumn{2}{|c|}{$\begin{array}{l}\text { Almospheric } \\
\text { Pressurc MCFC }\end{array}$} & \multicolumn{2}{|c|}{$\begin{array}{l}\text { Current } \\
(2 \mathrm{MW})\end{array}$} & \multicolumn{2}{|c|}{ Latcr than 1997} & \multicolumn{2}{|c|}{$\begin{array}{l}\text { Opcration with } \\
\text { BOP and Large } \\
\text { Salcs Volume }\end{array}$} & \multicolumn{2}{|c|}{$\begin{array}{c}\text { ERC (US) [Mclco } \\
\text { (Japan)] }\end{array}$} & $\begin{array}{c}\text { IHI (Japan), [Mclco (Japan), Toshiba (Japan), } \\
\text { Sanyo (Japan)] }\end{array}$ \\
\hline \multicolumn{2}{|c|}{ Pressurized MCFC } & \multicolumn{2}{|c|}{$\begin{array}{l}\text { Current } \\
(250 \mathrm{~kW})\end{array}$} & \multicolumn{2}{|c|}{ Later than 1997} & \multicolumn{2}{|c|}{$\begin{array}{l}\text { Operation with } \\
\text { BOP and Large } \\
\text { Sales Volume }\end{array}$} & \multicolumn{2}{|c|}{$\begin{array}{l}\text { MC-Power (US) } \\
\text { [IHI (Japan)] }\end{array}$} & $\begin{array}{l}\text { IHI (Japan) [BCN (The Nctherlands), Hitachi } \\
\text { (Japan), IFC (US), Mclco (Japan), MHI } \\
\text { (Japan)] }\end{array}$ \\
\hline \multicolumn{2}{|c|}{ Tubular SOFC } & \multicolumn{2}{|c|}{$\begin{array}{c}\text { Current } \\
(25 \mathrm{~kW} \text { and above) }\end{array}$} & \multicolumn{2}{|c|}{ Later than 1997} & \multicolumn{2}{|c|}{$\begin{array}{l}\text { Operation of larger } \\
\text { systcms with BOP } \\
\text { and Large Sales } \\
\text { Volume }\end{array}$} & \multicolumn{2}{|c|}{ Westinghouse (US) } & [MHI (Japan)] \\
\hline \multirow{2}{*}{\multicolumn{2}{|c|}{$\begin{array}{c}\text { Planar SOFC } \\
\text { (at } 20 \mathrm{~kW} \text { or morc) }\end{array}$}} & \multirow{2}{*}{\multicolumn{4}{|c|}{ Not determinable }} & \multirow{2}{*}{\multicolumn{2}{|c|}{$\begin{array}{l}\text { Feasibility } \\
\text { demonstration for } \\
\text { long-tcrm, } \\
\text { thermally self- } \\
\text { sustaining } \\
\text { operation }\end{array}$}} & \multicolumn{3}{|c|}{ Representative Active Developers } \\
\hline & & & & & & & & \multicolumn{3}{|c|}{$\begin{array}{c}\text { AlliedSignal (US), British Gas (UK), Ceramatec (US), Dornier } \\
\text { (Germany) and Cookson (UK), Fuji (Japan), Fujikura (Japan), GEC } \\
\text { (UK), Melco (Japan), MHI (Japan), Mitsui (Japan), Murata (Japan), } \\
\text { Norcell (Norway), Osaka Gas (Japan), Sanyo (Japan), Siemens } \\
\text { (Germany) and ECN (The Netherlands), Statoil (Norway), Sulzer } \\
\text { (Switzerland), Tonen (Japan), Ztek (US) }\end{array}$} \\
\hline PEMFC & \multicolumn{2}{|c|}{$\begin{array}{l}\text { Demonstration } \\
\text { jales: Time Period } \\
\text { \& Power Range }\end{array}$} & \multicolumn{2}{|c|}{$\begin{array}{l}\text { Commercial } \\
\text { Sales }\end{array}$} & \multicolumn{2}{|c|}{$\begin{array}{c}\text { Steps to } \\
\text { Commercialization }\end{array}$} & \multicolumn{2}{|c|}{$\begin{array}{c}\text { Technology } \\
\text { Leader }\end{array}$} & \multicolumn{2}{|r|}{ Representative Participants } \\
\hline Motive & \multicolumn{2}{|c|}{$\begin{array}{l}94 \text { (bus) - } 98 \\
40-50 \mathrm{~kW}\end{array}$} & \multicolumn{2}{|c|}{$\begin{array}{l}2005-2007 \\
\text { (DOE } \\
\text { Estimate) }\end{array}$} & \multicolumn{2}{|c|}{$\begin{array}{l}\text { Feasibility } \\
\text { demonstrations at } \\
\text { acceptable costs }\end{array}$} & & $\begin{array}{l}\text { Ilard } \\
\text { nada) }\end{array}$ & \multicolumn{2}{|c|}{$\begin{array}{l}\text { AlliedSignal (US), Allison Engine Co. (US), Analytic } \\
\text { Power (US), Chrysler (US), Daimler-Benz (Germany), } \\
\text { Dow/Ballard (US), Energy Partners (US), Ford (US), } \\
\text { Giner, Inc. (US), GM (US), IFC (US), Mazda (Japan), } \\
\text { MHI (Japan), Siemens (Germany) }\end{array}$} \\
\hline Stationary & & $\begin{array}{l}95-98 \\
\mathrm{~kW}-250 \mathrm{~kW}\end{array}$ & & 1999 & $\begin{array}{l}\text { Operatic } \\
\text { and larg }\end{array}$ & $\begin{array}{l}\text { n with BOP } \\
\text { numbers of } \\
\text { sales }\end{array}$ & & $\begin{array}{l}\text { illard } \\
\text { nada) }\end{array}$ & $\begin{array}{l}\text { All of the } 1 \\
\text { ElectroChe } \\
\text { Environme } \\
\text { Power (US } \\
\text { (US), Lynn } \\
\text { (Japan), Te }\end{array}$ & $\begin{array}{l}\text { Above, AISI (Japan), Bestech (US), } \\
\text { m (US), Eltron Research (US), Energy \& } \\
\text { ntal Corp. (US), ERC (US), Fuji (Japan), H- } \\
\text {, ICET (US), IFC (US), Interfacial Sciences } \\
\text { tech (US), Physical Sciences, Inc. (US), Sanyo } \\
\text { cogen (US), Westinghouse (US) }\end{array}$ \\
\hline
\end{tabular}




\section{APPENDIX: MEMBERS AND EX OFFICIO MEMBERS OF THE AFC2WG}

A.J. Appleby, Center for Electrochemical Systems, The Texas A \& M University System, College Station, TX 77843-3402; B.S. Baker, ERC, 3 Great Pasture Road, Danbury, CT 06813; J.L. Bates, Materials Sciences, MSIN K2-45, Pacific Northwest Laboratory, Battelle Blvd., P.O. Box 999, Richland, WA 99352; L.B. Buss, Space Systems Engineering, AlliedSignal Inc., Aerospace Systems \& Equipment, $2525 \mathrm{~W}$. 190th Street, 93140/T41, Torrance, CA 9(1504-6099; E.J. Cairns, Energy \& Environment Division, Bldg. 90, Rm. 3030, Lawrence Berkeley Lab, Lniversity of California, Berkeley, CA 94720; L. Camara, M-C Power, 8040 South Madison St., Burr Ridge, IL 60521-5808; S.G. Chalk, U.S. Department of Energy, Office of Energy Efficiency and Renewable Energy, EE-321, Office of Transportation Technologies, Washington, D.C. 20585; T.-P. Chen, Bechtel Corporation, 50 Beale Street, San Francisco, CA 94119 3965; H.F. Creveling, Allison Corp., Allisor Engine Co., P. O. Box 420, S.C. S-51, Indianapolis, IN 46206-0420; W.J. Dollard, Advanced Energy Conversion Division, Westinghouse Electric Corp., Science \& Technology Center, 1310 Beulah Road, Pittsburgh, PA 15235-5098; L.H. Dubois, Advanced Research Projects Agency/Defense Sciences Office (ARPA/DSO), 3701 No. Fairfax Drive, Arlington, Virginia 22203-1714; P.J. Farris, IFC Corporation, 195 Governors Highway, P.O. Box 739, South Windsor, CT 06074; R.B. Fleming, Ballard Power Systems, 6591 Morning Tide, Huntington Beach, CA 92648; S.H. Folstad, Technology and Business Developmert, IFC Corporation, 195 Governors Highway, P.O. Box 739, South Windsor, CT 06074; F. D. Freeburn and R. Rosenthal, Research and Technical Assessment Division (ST-112), Office of Program Analysis, Office of Science and Technology, U.S. Department of Energy, Washington, D.C. 20585; E.A. Gillis, Fuel Cells, EPRI, 3412 Hillview Ave., Palo Alto, CA 94304; J.A. Gunsher, Ventures Department, The Dow Chernical Company, 2030 Dow Center, Midland, MI 48674; M. Hsu, Ztek Corporation, 460 Totten Pond Road, Waltham, Massachusetts 02154; J.J. Kennedy, Space Systems, AlliedSignal Inc., Aerospace Systems \& Equipment, 2525 W. 190th Street, 93140/T41, Torrance, CA 90504-6099; A. Khandkar, Ceramatec. Inc., 2425 South 900 West, Salt Lake City, UT 84119; J.A. Kimball, Energy Conversion, GRI, 8600 West Bryn Mawr Ave., Chicago, IL 60631; K. Krist, Inorganic Chemistry, GRI, 8600 West Bryn Mawr Ave, Chicago, IL 60631; M. Krumpelt, Chemical Technology Division, Argonne National Laboratory, Argonne, IL 60439; J.W. Landis, Stone \& Webster Enginecring Corp., P.O. Box 2325, Boston, MA 02107; R.A. Lemons, MS D429 Los Alamos National Laboratory, Los Alamos, NM 87545; L.G. Marianowski, Energy Conversion and Storage Research, IGT, 1700 South Mount Prospect Road, Des Plaines, IL 60018-1804; H. Maru, ERC, 3 Great Pasture Road, Danbury, CT 06813; M.J. Mayfield ${ }^{*}$, U.S. Department of Energy, Morgantown Energy Technology Center, P.O. Box 880, 3610 Collins Ferry Road, Morgantown, West Virginia 26507-0880; J.B. O'Sullivan, Fuel-Cell Commercialization, EPRI, 3412 Hillview Ave., Palo Alto, CA 94304; L.T. Papay, Bechtel Corporation, 50 Beale Street, San Francisco, CA 94119-3965; P.G. Patil, U.S. Department of Energy, Office of Energy Efficiency and Renewable Energy, EE-321, Office of Transportation Technologies, Washington, D.C. 20585; C.E. Pax, U.S. Department of Energy, Office of Fossil Energy, FE-73, Washington, D.C. 20585; S.S. Penner, AFC2WG Chairman, UCSD, 9500 Gilman Drive, La Jolla, CA 92093-0411; M. Raber, General Public Utilities Service Corporation, 100 Interpace Parkway, Parsippany, NJ 07054; G. Runte, General Public Utilities Service Corporation, 100 Interpace Parkway, Parsippany, NJ 07054; R.F. Savinell, Case Center for Electrochemical Sciences, Case Western Reserve University, 10900 Euclid Ave., Cleveland, Ohio 44106-7217; J. R. Selman, Dept. of Chemical Engineering, Armour College of Engineering, IIT Center, Chicago, IL 60616; D.A. Shores, Dept. of Chemical Engineering and Materials Science, 151 Amundson Hall, University of Minnesota, 421 Washington Ave., Minneapolis, MN 55455; S. Swathirajan, Physical Chemistry Dept., GM Corp., North American Operations, R \& D Center, 30500 Mound Road, Box 9055, Warren, MI 48090-9055; J. Talbot, Dept. of Chemical Engineering, UCSD, 9500 Gilman Drive, La Jolla, CA 92093-0411; P. Tarman, M-C Power, 8040 South Madison St., Burr Ridge, IL 60521-5808.

\footnotetext{
* Deceased September 8, 1994.
} 
